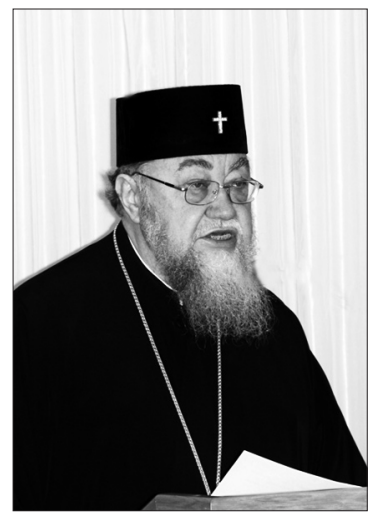

Ks. Metropolita Sawa (Hrycuniak)

SŁOWO WSTEPNE

\title{
Czcigodne Audytorium,
}

otwierając konferencję Katedry Teologii Prawosławnej Uniwersytetu w Białymstoku na temat „Sztuka sakralna i jej wpływ na duchowość człowieka", serdecznie witam wszystkich zebranych.

W dniu dzisiejszym koncentrujemy się na ważnym przejawie życia cerkiewnego, jakim jest sztuka sakralna, która odgrywa duże znaczenie w życiu Cerkwi. Zwrócimy szczególną uwagę na jej wpływ na życie duchowe człowieka. Początki sztuki sięgają czasów najdawniejszych i jest ona jedną z wielu form przekazu ludzkiego działania i doświadczenia chwały Bożej. Oddziaływanie Boga jako Istoty Najwyższej i Najdoskonalszej odbywa się w piśmie, ikonografii, śpiewie i budownictwie, czyli architekturze. Dla chrześcijaństwa wszystko to, co w sztuce prowadzi do duchowego wzbogacania się, odgrywa wielką i znaczącą rolę. Święci Ojcowie zalecali, by mistrz, ikonograf, pisarz, budowniczy nacechowany był głęboką wiarą, wówczas twórczość jego można określić co do jego moralności, estetyki, a nade wszystko bogactwa ducha. Św. Teodor Studyta pisze że: „od obrazu Chrystusa, który jest wzorem wszelkiego obrazu, wznosimy wzrok naszego ducha do nieśmiertelnego obrazu Boga”. W II Liście Apostoła Pawła do Koryntian czytamy: „Ale my wszyscy z odkrytym obliczem patrząc 
w zwierciadle na chwałę Pańską, w ten sam obraz się przemieniamy" (2 Kor 3,18).

W ten sposób Bóg uczynił z serca organ do poznania Jego chwały, bowiem światłość Jego oświeca oblicze świętych! Prawdziwe piękno nie ma potrzeby udowodniania siebie. Piękno, mówił Platon, jest odblaskiem prawdy. Prawdą tą jest sam Bóg. Dlatego święci modlili się, by kontemplacja Boga rozciągała się na wieczność. Sztuka zatem przemienia człowieka mocą swego piękna. Jest ona czystą jakością i Jej owoce są niepowtarzalne. Sztuka Boska wymaga łaski i profetycznego charyzmatu, prezentuje bowiem to, co Jest niewidzialne.

W całej historii ludzkości stanowiła ona metafizyczny element talentu ludzkiego, jego czysty ideał. Dlatego stanowi zawsze spoiwo organizmu społecznego, więź między percepcją i wyobraźnią. Dlatego zawsze posługiwano się wizualną formą przekazu. W Grecji osiągnęła ona najwyższe szczyty w swoich dziejach.

Poprzez swój immanentny związek z wartościami uniwersalnymi sztuka jawiła się jako objawienie boskości. Zawsze artystów uważano za ludzi natchnionych, twórców, za istoty zawieszone między ziemią a niebiosami. Sztuka jest czystą jakością, jej owoce są niepowtarzalne. Wartość, jaką wytwarza, stanowi wartość estetyczną, wzbogaca wartości materialne, ale oddziałuje na stan ducha człowieka. Zawsze i wszędzie jest wytworem kultury ducha ludzkiego trudno byłoby zrozumieć historie i jej sens, i na odwrót. O tym będzie mowa w dzisiejszych referatach.

Należy podkreślić, że muzyka, szczególnie cerkiewna, jest jedną spośród sztuk. Ikona zaś w swej wartości symbolu przewyższa sztukę i ją wyjaśnia. Jest najwyższym jej osiągnięciem.

Św. Jan Damasceński pisze: „Kiedy męczą mnie myśli i przeszkadzają mi cieszyć się przyjemnością czytania, udaję się do świątyni, mój wzrok zostaje przykuty do jej architektonicznej przestrzeni i skłania mą dusze do chwały Bożej. Rozmyślam męczennika... jego płomienność mnie zapala... padam na ziemie, by adorować Boga za pośrednictwem męczennika”. 
Na koniec trzeba stwierdzić, że kiedy sztuka zapomina o sakralnym języku symboli, o jego obecności, i zaczyna traktować je plastycznie, wówczas tchnienie transcendencji przestaje je przenikać.

Uchwały soborowe zalecają, aby nad wszystkim co się zwie sztuką pracować „z bojaźnią Bożą, gdyż jest to sztuka Boska”. 